\title{
Learned Societies, Cultural Encounter, and Social Distinction: The Royal Asiatic Society and Pre-War Western Relations with Korea, Japan, and China
}

\author{
LOUGHLIN J. SWEENEY*
}

The Royal Asiatic Society (RAS), a British learned society for the antiquarian study of Asian civilizations, established a number of branches in East Asia between 1865 and 1900 and quickly became a central location for the socialization of elite westerners within these states. This paper examines the social function of three RAS branches by analyzing their membership characteristics between 1865 and 1934, and draws out the role of Western associational culture in pre-war interactions between Western states and Northeast Asia. The activities of the RAS presented an opportunity for prominent personalities to demonstrate social distinction and reinforce their status as leading members of their communities, and to make claims to local expertise through the study and discussion of East Asian societies. RAS branches attracted a diverse mixture of diplomats, customs officials, military officers, missionaries, educators, merchants and medical professionals. Through a comparative analysis of the membership characteristics of RAS branches in Seoul, Tokyo, and Shanghai (the branches covering Korea, Japan, and North China respectively), the different social structures of the Western communities in these three states can be discerned. These reflect particular aspects of international relations between Northeast Asia and the West before the Second World War.

Keywords: Northeast Asia; European imperialism; diplomatic history; Royal Asiatic Society; Korea; China; Japan

* Assistant Professor, Endicott College, Woosong University, South Korea; E-mail: lsweeney@endicott.ac.kr

DOI: $10.16934 /$ isr/20.2.201912.73 


\section{INTRODUCTION}

Modern political relations between Northeast Asian and Western states can be said to have begun in the late nineteenth century, as Asia was assimilated into an increasingly global international order (Kim 1980; Jun 2011; Anthony and Neff 2016). The exposure of Asian markets to the world economy and the normalization of diplomatic relations was occasioned by the transaction of successive 'unequal treaties', beginning with the Treaties of Nanking (1842), Kanagawa (1854), and Ganghwa (1876) for China, Japan, and Korea respectively. In the early stage of the development of this new, treaty-based international order in Northeast Asia, European imperial powers regarded in-depth information about East Asian states as a rare and valuable commodity (Bickers 1999). Accordingly, Western consular and diplomatic officials in East Asia were called upon to act not solely as functionaries, but as amateur anthropologists, historians, and geographers, collecting intelligence which might serve the strategic interests of their government; accruing intellectual capital and developing imperial knowledge was a key aspect of power projection (Crosbie 2009; Osborne 2005). In a period when policymakers in the European capitals were not always certain of even the basic geography of East Asia (see, for example, Walton 1900), the rapid collection and transmission of information was crucial in the contest for influence between the imperial powers.

This paper examines one manifestation of this push for information and strategic advantage, the establishment of branches of the Royal Asiatic Society (RAS), a British learned society dedicated to the scholarly study of Asian societies, histories, and cultures, in various Northeast Asian localities between the 1860s and the 1930s. It will focus specifically on the RAS branches in Shanghai (known as the North China Branch, NCBRAS, and also covering Beijing), Seoul (the Korea Branch, RASKB), and Yokohama (the Asiatic Society of Japan, ASJ). The membership profiles of these organizations will be drawn from their surviving publications, revealing, it is contended, the characteristics of the leading groups within Western societies in Northeast Asia. This membership information can provide new evidence in three important areas: first, the involvement of imperial diplomats and civil servants in these organizations can illustrate the importance Western governments placed on collecting granular information on East Asian states, cultures, and societies, and can afford some insight into the strategic value of this information. Second, examining the membership profile of Royal Asiatic Society branches comparatively can illustrate the differing ways in which Western states interacted with East Asian states, revealed through the differing social hierarchies present within each Western community. Third, RAS memberships can illustrate whether informal networks were an important feature of international relations between the West 
and Northeast Asia in this early period between the mid-nineteenth century and the outbreak of the Second World War.

\section{Regional background: informal empire and antiquarian encounter amid the Westphalian shift in East Asia c.1860-1910}

Kim Key-hiuk (1980) identifies the late nineteenth century as a crucial period in the history of Western relations with East Asia, as the 'East Asian world order,' a self-contained system of regional arbitration with the figure of the Chinese emperor at its centre and little connection to wider global affairs, gave way to the Westphalian international order based on concepts of international law, bipartisan treaties, imperial contestation, and gradations of civilization (Lai 2014; Blaut 1993). According to Park Seo-hyun (2013), the period was typified by contested and shifting definitions of sovereignty and civilization, as the two concepts of world order interacted with each other, and with evolving practices and standards of diplomacy, security relationships, and the expansion of markets. This shift allowed for the proliferation of Western communities throughout East Asia, in the treaty ports through which trade with the Chinese interior was transacted, in formal European colonies such as Hong Kong and Macao, and in newly-established foreign legations and trading communities in Beijing, Seoul, Tokyo, and the principal ports of the region (Van Dijk 2015). These were principally occupied by military personnel, consular and diplomatic staff, and merchants, though as the nineteenth century gave way to the twentieth an increasingly broad proliferation of missionaries, medical and legal professionals, and members of a host of other ancillary professions were increasingly in evidence in growing communities of Westerners throughout East Asia (Bickers and Howlett 2016; Jackson 2016; Anthony and Neff 2016; Bickers 1999).

Western consular officials were recruited largely from university graduates who had demonstrated a particular talent as Chinese linguists, and this educated professional class proved an ideal fit for the goal of collecting and disseminating information about East Asian civilization and culture. Consuls of many nations, but principally the British and Germans (Cho and Roberts 2018; Clifford 2001), travelled extensively through the region, writing travelogues, performing geographical surveys, collecting economic data, and uncovering the ancient history of East Asian states (see, for example, Campbell 1892; Allen 1908). At the same time, their diplomatic clout created room for European navies to perform coastal surveys, and for Western missionaries to operate throughout the region, becoming deeply conversant in the subtleties of culture and society across the class structure (Underwood 2003). The usefulness of all of this antiquarian interest in East Asian societies is clearly expressed in the writings of European policymakers (Walton 1900; Beresford 1899), and the importance of 
scientific inquiry to the extension of imperial control was a recurring theme in late nineteenth century political discourse: one need look no further than the role of the Royal Geographical Society in creating the conditions for the scramble for Africa to discern this (Bell, Butlin, and Heffernan 1991). The dominant commercial and military power in East Asia in the mid-nineteenth century was Great Britain; as it extended its interests in the region, the institutions generating British influence followed, including the Royal Asiatic Society.

\section{The establishment of Royal Asiatic Society branches in East Asia}

The Royal Asiatic Society of Great Britain and Ireland was first established in London in 1823. It had played an important role in expanding British influence in South Asia, in organizing and coordinating the antiquarian activities of East India Company employees who sought to study ancient Indian civilization. More than simply a society of Orientalist interest, the Royal Asiatic Society became part of an imperial scientific apparatus that reinforced British authority, allowed for the performance of social distinction, and generated a source of 'respectability' among its members as knowledgeable, enlightened imperialists (Reed 2016; Crosbie 2009). From 1847 it began to extend its activities, following in the heels of British imperial expansion and establishing its first East Asian branch in the newly-acquired colony of Hong Kong. Further branches followed, with the society establishing itself in Shanghai in 1857, in Japan in 1872, the Straits Settlements in 1877, and Korea in 1900. The Shanghai branch became defunct in the 1950s but was resurrected in 2006, and the Japanese and Korean branches are still active.

The three branches under consideration existed at the center of a heavily interconnected network of Western interaction in Northeast Asia, of diplomatic maneuvering, trading activity, naval power projection, and contests over commercial concessions and access to raw materials (Van Dijk 2015). Surviving accounts from the late nineteenth century, such as that of the American businessman Walter Townsend, illustrate a highly mobile population of commercial and consular traffic circulating between Shanghai, Tokyo, and Seoul, which provided a renewable source of interested members for the new RAS branches (Cook 1981). All three Northeast Asian branches, in Shanghai, Seoul, and Yokohama, were borne of two mothers: in the early years of their establishment, they relied on the support of British diplomatic elites and American missionaries. The North China Branch was established by the missionary Elijah Coleman Bridgeman, and the re-established branch of the 1860s boasted the British consul-general, Harry Parkes, as its president. Senior staff of the British legation were always to be found on its executive committee, and in the lists of honorary members. The Asiatic Society of Japan, likewise, was 
originated by the British consul Robert Watson, with significant support and assistance from the American missionary and linguist James Curtis Hepburn (ASJ 1873). The Korea Branch's first and second presidents were British consuls, J.H. Gubbins and John Jordan, while the majority of the early work of the society was performed by American and Canadian missionaries, such as James Scarth Gale, Horace Underwood, and Henry Appenzeller.

As well as its utility as a locus for Anglo-American elite interaction, the usefulness of the substance of the RAS's work, the collection and analysis of information about the geography and society of China, Japan, and Korea, was summarized by the preface to the first issue of the Journal of the North China Branch of the Royal Asiatic Society, published in 1860:

The importance of adding to the limited stock of information we possess, respecting the Chinese, is acknowledged on all hands. We are entering a new era in our political relations with them; the exclusive policy, which for centuries has closed this great empire to the world, must shortly be relaxed $\cdots$ problems are presented in the solution of which the statesman, the philosopher, and the missionary are all deeply interested. (NCBRAS 1860)

The problems presented by the inculcation of Northeast Asia into the international system, Bridgeman goes on to say, can only be resolved through intimate acquaintance "with their minds, their direction of thought, and the standpoint from which they survey the great questions which our policy and civilization present'. The strategic utility of the Royal Asiatic Society in Northeast Asia, then, was its potential for knowledge collection and exchange.

\section{Establishing a picture of RAS membership}

The majority of the data drawn on for this article comes from the annual publications of the RAS branches, still housed in their libraries. The Royal Asiatic Society Transactions not only give an account of the meetings held by the branches, their frequency, and the topics discussed; they also include information about the composition of the society, its structure and characteristics. This data has been supplemented by the records of other important Western-run institutions in Northeast Asia, such as the Chinese Maritime Customs Service, as well as the memoirs and writings of individual members and other resident Westerners from the period.

A limitation of the RAS membership lists as sources is the inconsistency of the information they present; from year to year, branches did not always collect and publish the same information, so that for some years we have a 
comprehensive list of members' addresses, occupations, and date of joining; while for other years, we may only have a list of names. Additionally, there are some internal inconsistencies in the data: for example, a membership secretary's report might claim that the branch had attracted twenty new members that year, but the membership list will report fewer new members. No consistent tally was kept of the branches' attrition rates (although occasionally the deaths of members are commemorated, and unusually high rates of loss were discussed at the annual meetings of the executive committee). In the early years of a branch's existence it may have fallen defunct multiple times before becoming established, and thus it is not always clear to what extent membership fluctuated in a newly-established branch. Additionally, accounts of minutes, and supplementary information relating to branch members, is frustratingly limited, which prohibits more extensive discussion of particular cases of elite interaction within the context of the RAS branches.

Nonetheless, sufficient information exists to sketch out the long-term trends in the life of these RAS branches. Information was collected, where available, on total membership numbers, categorized by gender, location, nationality, and occupational category (consular/diplomatic service, customs officers, medical professionals, missionaries and clerics, military officers - and where known: fellows and university professors, businesspeople, and journalists). The branch officers tended to be well-known individuals of significant standing in the consular, diplomatic, or military services of the European imperial powers, so the extent of their involvement with the Society is also of note. Many leading RAS members were also pioneering figures in the field of Asian studies, such as Ernest Satow, Thomas Wade, and Herbert Giles.

The data presented in this article emerges primarily from the membership lists published in the annual Transactions of the RAS branches. In some years these contain more in-depth information, but in every year they present at minimum a list of names of members, divided into 'honorary', 'corresponding', and 'resident' categories. From this a total count of branch members was obtained, as well as the number of members' resident in-country versus overseas. This method has been used to insightful effect in studies of the history of institutions and society, such as Tanja Bueltmann's (2017) work on the associational culture of Scottish expatriates in Asia, or Seán Gannon's (2016) work on imperial policing. From the archive of available membership lists, data was collected at approximately five-year intervals, though this was not always possible due to gaps in the archive.

Based on the titles utilized in the membership lists, the various professions represented in each branch can be conjectured: military ranks (Lt., Capt., Maj. etc.) and service branches (RM for Royal Marines; RMA for Royal Maritime Artillery, etc.) are recorded, as are academic and religious qualifications (Dr.; 
Rev. Dr.; Dr. Prof. etc.). Diplomatic titles and titles of nobility (Hon.; Prince) also make an appearance, and supplementary research on these individuals usually reveals their occupational background - mainly these individuals were attached to diplomatic missions. By comparing RAS membership lists with the employment lists of the Chinese Maritime Customs Service (SOAS Maritime Customs Papers V, No. 44, 1859-1921), an approximation of the number of customs officials in each RAS branch was arrived at. In other years, this information was provided via listed addresses of members in the Transactions. The Korea Branch, the only branch which had a significant female membership, also recorded the gender of each member.

The Transactions of the three RAS branches, and the data they contain pertaining to their members, will now be examined comparatively. ${ }^{1}$

\section{THE NORTH CHINA, JAPAN, AND KOREA BRANCHES COMPARED}

\section{Early developments: RAS membership in the late nineteenth century}

Of the three branches under examination, North China was the first to be established, in 1857. It had a fitful early existence, in parallel with the condition of China at large in the 1850s (Osterhammel 1999). With the conclusion of the Second Opium War in 1860, and the resumption of 'normality' in the Chinese treaty ports, the Society was re-established in Shanghai in 1864 with a membership of twenty-six. The Western community in Shanghai proved a fertile recruiting ground, and by the following year membership had ballooned to ninety. Membership continued to grow steadily to a high of 205 members in 1875, after which it began to fall off, bottoming out with a low of 135 in 1881 .

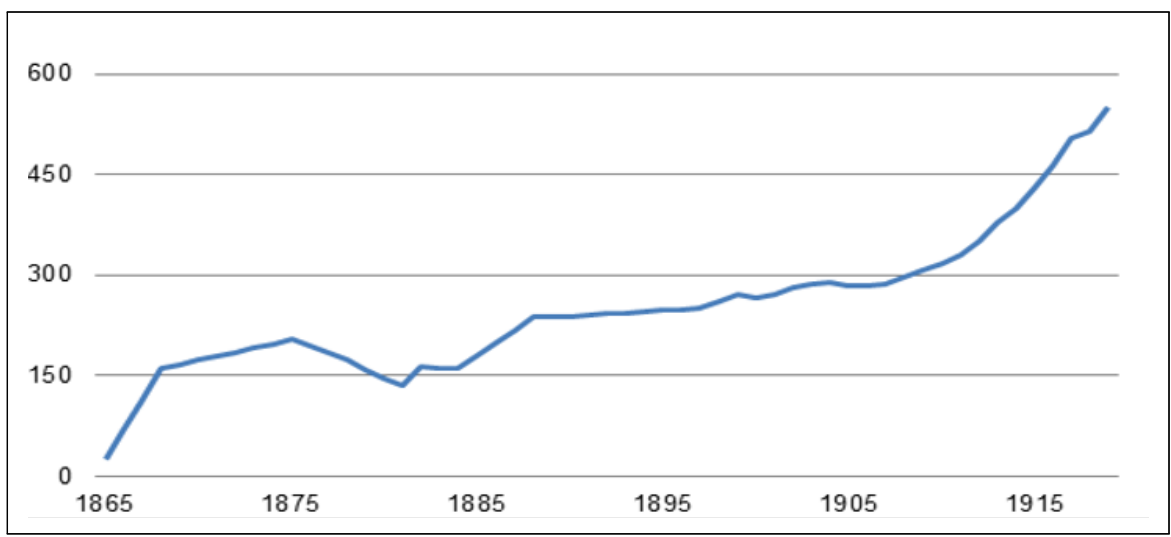

FIGURE 1. MEMBERSHIP OF THE NORTH CHINA BRANCH OF THE ROYAL ASIATIC SOCIETY, 1864-1920 
What was the cause of this dip? The membership characteristics of the branch invite a few possibilities. The Shanghai RAS in its early years had a distinctly British character, and in the late 1870s the British population of Shanghai was declining. The dip and subsequent growth in membership thus mirrors wider trends in the Western population of Shanghai (Bickers 2010). The subsequent expansion of the Shanghai RAS membership was much more cosmopolitan: in 1880, only five members of the society could be identified as non-British, whereas by 1887 there were thirty-five non-British members, and a decade later fifty-eight. The significant increase in German, French, Russian, and American members corresponds with the increasing challenge these nations posed to British strategic and commercial supremacy in East Asia in the 1880s and 1890s (Schmid 2002).

There was also a cultural, and perhaps generational, shift taking place in the settlement which depressed membership: the annual address of the president of the society in 1874, amid early signs of declining interest, noted that 'the public is too apt to look upon us as an assemblage of dryasdusts and crochet-mongers, held together by the necessity of mutual admiration' (NCBRAS 1874). As Robert Bickers (2010) suggests, while the RAS continued to be regarded as a 'public resource', nonetheless 'scholarship remained a minority pursuit', particularly with the increasing availability of other diversions in the 1870s and 80s, such as the town orchestra, various social and sporting clubs, and the Shanghai Volunteer Corps, all competing for the limited leisure time of Western professionals.

It was not long, however, before interest in the society began to pick up. The councilors' report for 1883 reveals, with a distinct sense of relief, that 'the meetings of 1883 were better attended, and greater interest evinced in the papers that were read than has been the case for some time past' (NCBRAS 1883). What is clear, however, is that the society's recovery in the late 1880s relied on the largesse and the professional network of one man: Robert Hart, the inspector-general of the Chinese Imperial Maritime Customs. The Journal of the North China Branch records that, with memberships declining and the society struggling to meet its expenditures over its library and museum, Hart donated a substantial sum to help balance the accounts (NCBRAS 1882). Employees of the Maritime Customs also contributed to the rapid recovery of the society from the late 1880s, subscribing in record numbers and sustaining their interest through the turn of the century. In 1888 alone, fifty-eight customs officials joined the society, which increased the size of the branch by almost a quarter (NCBRAS 1888).

Aside from a brief hiatus in growth in the years of the Boxer rebellion (1899-1901), the North China Branch continued to attract members at an accelerating pace. By 1920, the society could boast a membership of over 500. Its political reach was extended as former resident members returned to Europe and the United States to continue their careers. The lists of overseas members 
continued to grow, and by the twentieth century depicts a network of influential personnel stretching across the world's capitals and seats of learning, to Washington and Whitehall, as well as Cambridge, Oxford, and Harvard (NCBRAS 1899).

TABLE 1. NORTH CHINA RAS MEMBERS BY PROFESSION

\begin{tabular}{lcccc}
\hline & $\mathbf{1 8 6 8}$ & $\mathbf{1 8 8 0}$ & $\mathbf{1 8 9 7}$ & $\mathbf{1 9 1 8}$ \\
\hline Consular and diplomatic officials & 5 & 6 & 47 & 42 \\
\hline Religious & 15 & 18 & 30 & 53 \\
\hline Medical & 15 & 10 & 16 & 34 \\
\hline Military & 9 & 5 & 1 & 7 \\
\hline Customs officers & 3 & 4 & 37 & 31 \\
\hline
\end{tabular}

The fluctuating fortunes of the Royal Asiatic Society in these years reflected the international situation in China, and is illustrative of the effect of geopolitical imperatives on the life of the communities exposed to them. As Shanghai and other treaty ports and customs posts in North China recovered from the upheavals of the war of 1856-60, European society in China began to acquire the trappings of permanency: as the society's own record of occurrences notes, 'a large measure of prosperity has been enjoyed $\cdots$ in the foreign settlement, the tide of population has advanced, and domestic and foreign influence increased $\cdots$ This prosperous state of affairs [is due to] the foreign elements, social, political, commercial and religious' (NCBRAS 1860). As a 'settled' (Bickers 2016) population began to emerge to administer relations between China and the West in the 1870s and 80s, the strategic importance of the work performed by the RAS declined, and public interest was attenuated. It was only the foresight of Robert Hart, regarded at the time as one of the most insightful political operators in China (Nish 2005; O'Conor 1893), who recognized its use to the Customs Service, and allowed for its continued functioning. As the contestation over trade and strategic influence in Northeast Asia heated up in the 1880s and 1890s (Lensen 1982), the composition of the North China Branch correspondingly changed to reflect these political realities.

The febrile international situation in Northeast Asia in the late nineteenth century was exacerbated by the ongoing programme of industrialization and Westernization in Japan (Uchida 2011). This ensured that the Asiatic Society of Japan, founded in 1872, would continue to attract significant attention from Western diplomatic and business interests throughout this period.

The Japanese branch of the Asiatic Society (which never adopted the 'royal' designation to accommodate Japanese members sensitive to the impression of divided loyalties - a courtesy not extended by the Korean and Chinese 
branches) rapidly accrued a healthy membership after 1872 . Many of its early members, including those serving on its executive committee, continued to be active members of the Shanghai branch, as well. The Japanese branch was headquartered in Yokohama, which, although a major port and an important node in the Pacific trade network (Cook 1981), could not boast a large and well-developed Western population like that of Shanghai. Accordingly, attracting Japanese members to the society was a key consideration. While the society's presidents, including James Hepburn and Harry Parkes, made steps to try and facilitate this, the Japanese membership of the society remained low, with only a handful of Japanese political elites, doctors, lawyers, and other professionals joining, such as the noted medical authority Keisuke Ito, also a member of the North China Branch, and the biologist and linguist Sakurai Joji (NCBRAS 1888; ASJ 1913). The Asiatic Society is of significant importance to the history of Japanese international relations due to the heavy involvement of Sir Ernest Satow, the British consul and fervent Japanologist, the 'father' of the AngloJapanese alliance of 1902 (Brailey 1992).

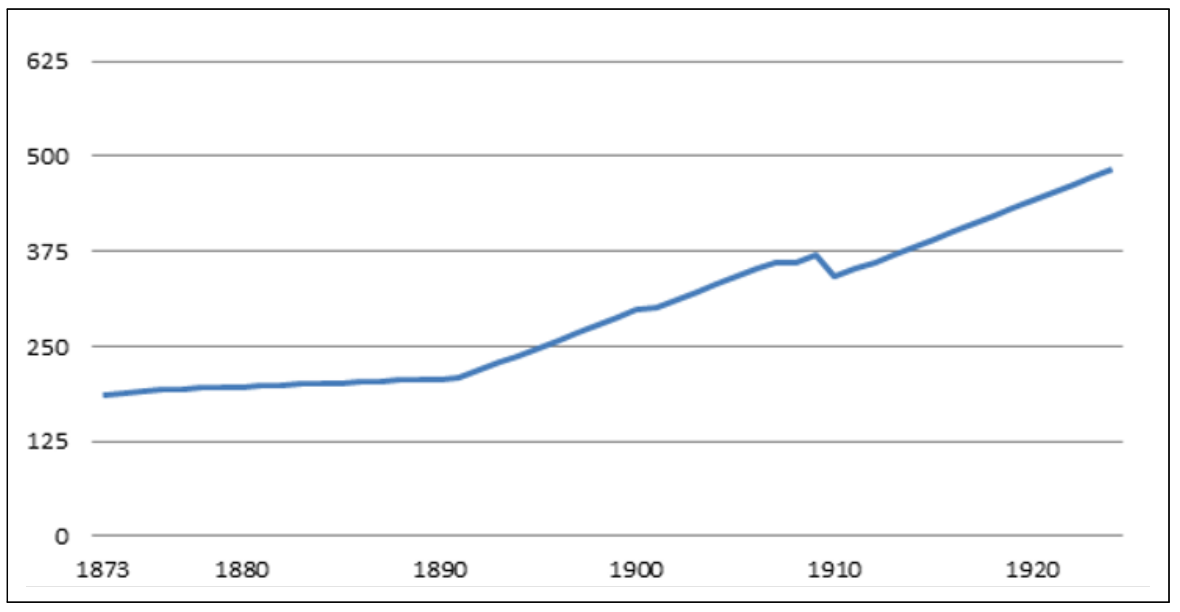

FIGURE 2. MEMBERSHIP OF THE ASIATIC SOCIETY OF JAPAN 1873-1924

\section{The Northeast Asian RAS branches in the twentieth century}

As Western communities in East Asia continued to grow, the utility of the RAS branches as a method of collecting information of strategic value diminished, and the society's function began to change. By the twentieth century, the Western presence in East Asia was well established, and in commercial centers like Shanghai, RAS membership accordingly skyrocketed. However, along with this explosion of interest, there was also a correspondingly high attrition rate, as 
members' yearly subscriptions lapsed and were not renewed. The North China branch in the 1910s welcomed an average of forty new members per year, but at the same time was losing almost half of that number in lapsed memberships and deaths (NCBRAS 1919). Similarly, the Japanese committee complained of the 'non-payment of dues' from a 'somewhat large number of delinquents' (ASJ 1910). The RAS branches had attracted a widespread membership, and were no longer defined by a small group of dedicated regular contributors; its social role within Western society in East Asia had shifted. However, as can be seen in the inauguration of the newest RAS branch in Seoul in 1900, the longstanding veterans of the RAS, diplomatic elites such as William Aston, Harry Parkes, Henry Merrill, John McLeavy Brown, J.H. Gubbins, and Horace Allen, would continue to play a central role in the society, and it accordingly continued to function as a vehicle for elite associationalism, and the generation of influence.

The Korean branch's late founding is reflective of the fact that Korea was the last of the Northeast Asian states to host a Western community. It was first opened to trade in 1876 with the Ganghwa Treaty, but trade was operated exclusively by Japan until 1883, when Westerners were finally permitted to reside in the country (Schmid 2002). A Western settlement sprang up at Chemulpo (part of present-day Incheon), and Western legations were established in Seoul. By the turn of the twentieth century Korea had become a popular location for Protestant and Catholic missionary activity, and the United States and various European powers had negotiated lucrative mining concessions, as well as regularly utilizing Korean ports to harbor their navies (Woo 1987; Deuchler 1977).

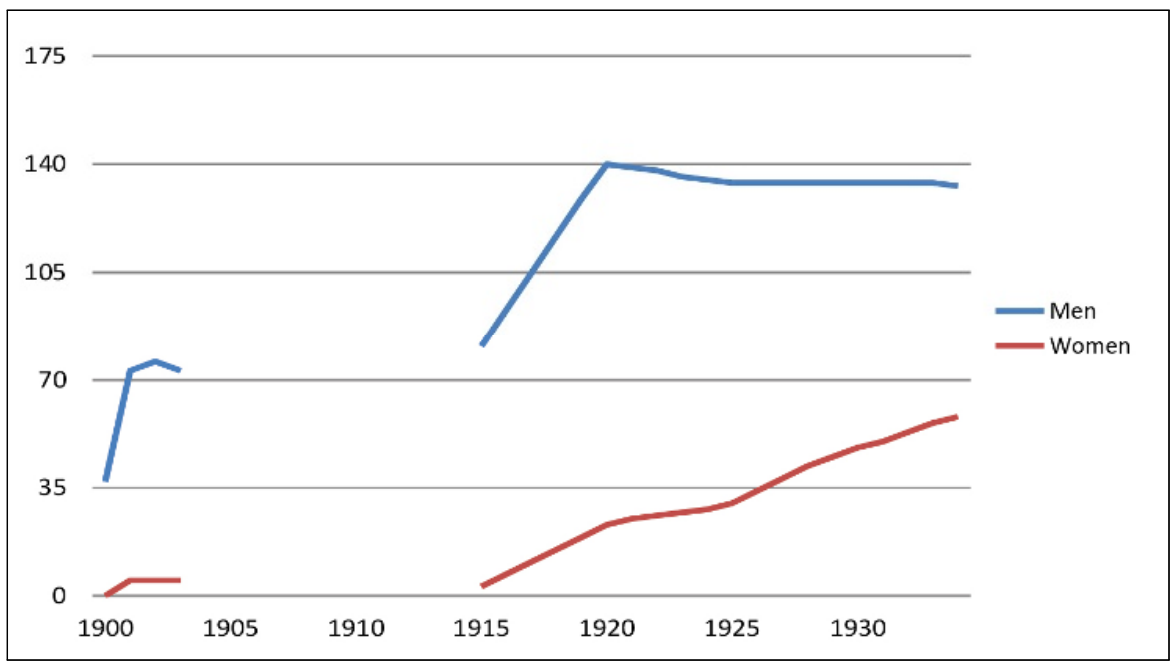

*n.b. The Korea Branch of the RAS held almost no meetings between 1902 and 1912.

FIGURE 3. MEMBERSHIP OF THE ROYAL ASIAIC SOCIETY KOREA BRANCH, 1900-1934. 
The early years of the Korea Branch were turbulent. Its organizers, which included the British and American consuls-general, struggled to recruit members from a small and diffuse Western population. Between 1902 and 1912, the society was defunct, and no papers were read at its infrequent meetings. In the 1910s, following the establishment of Japanese imperial rule in Korea, the Western population increased and the society began to expand (RASKB 1915).

The Korea branch's most apparent characteristic was its large proportion of missionary members. In the late nineteenth and early twentieth centuries North American missionaries heavily targeted Korea; between 1884 and 1934 over 1,000 North American and British missionaries were dispatched to Korea, engaged in proselytizing as well as founding schools and hospitals (Underwood 2003). Of those, several dozen were active members of the Korea Branch of the Royal Asiatic Society. Due to the nature of their work, this meant that the membership of the Korea branch was distributed widely around the Korean peninsula. In its characteristic mixture of consular officials and religious workers, it resembled the Shanghai branch before the 1880s.

TABLE 2. RAS KOREA BRANCH MEMBERS BY PROFESSION

\begin{tabular}{lccc}
\hline & $\mathbf{1 9 0 0}$ & $\mathbf{1 9 1 5}$ & $\mathbf{1 9 3 4}$ \\
\hline Consular and diplomatic officials & 7 & 7 & 3 \\
\hline Religious & 25 & 31 & 61 \\
\hline Medical & 5 & 18 & 16 \\
\hline Military & 0 & 0 & 4 \\
\hline Customs officers & 1 & 2 & - \\
\hline
\end{tabular}

Reflecting a membership which was more missionary than diplomatic or military, the questions considered by the Korean branch were also primarily cultural in nature. This gives the early Korean RAS' Transactions a more antiquarian feel when compared to the North China Branch's journal, which on occasion reads more like a field report from customs officers tracking trade routes (NCBRAS 1884) than a scholarly journal. The differing circumstances of the three branches' foundation is reflective of three different policy stances between Western powers and Northeast Asian states. The implications of these differences are examined in the following section.

\section{THE RAS AND WESTERN ENCOUNTER IN NORTHEAST ASIA}

The geopolitical implications underlying the fluctuating fortunes of the Royal Asiatic Society branches are indicative of the developing relations between Northeast Asia and the West at a number of levels. In the broadest sense, the 
RAS was engaged in a process of place-making as it sought to categorize and digest the characteristics of China, Korea, and Japan and situate them in the international order. Discussions of civilizational characteristics were not merely of antiquarian interest in this period, but rather were central to the Western imperial worldview in which East Asia was becoming immersed (Park 2013; Kim 1980). The RAS was intimately bound up in British strategic interests through the involvement of consequential figures such as Ernest Satow, Robert Hart, John Jordan, Thomas Wade, Herbert Giles, Rutherford Alcock, and Harry Parkes. Through the activities of linguists, religious instructors, and scholars, it linked Anglophone academia to the establishment of early universities throughout the region. In North China, it appears to have played an increasingly important role in circulating information and forging contacts between the business community in the treaty ports and the Chinese Maritime Customs (Van de Ven 2006). There may have been yet other important connections facilitated by the RAS, though they are not as easily discernable through examination of its membership profile alone.

The RAS branches are also indicative of more particular, local differences in Western encounter, most notably in their differing attitudes toward accepting Asian members. The North China Branch, reflecting the circumstances of its founding and its positioning within the semi-colonial space of the Shanghai international settlement, remained effectively closed to Chinese and other East Asian members for the entirety of the period under consideration. By the twentieth century, a handful of Chinese members had been admitted, but by and large the society was exclusively Western. The Japanese branch, by contrast, included local elites from the beginning (ASJ 1873). These differences reflected divergent imperial policies towards China, Korea, and Japan, but it is tempting also to read into them the different opinions held by Westerners on the relative merits of Japanese, Chinese, and Korean civilization in this period (Lai 2014). The function of the RAS branches as an avenue for cultural encounter was fraught with difficulties, as the articles in the branches' Transactions reveal: Western encounter with China was marred by the memories of the Second Opium War (1856-60), and a consistent feeling of peril among Westerners in the Chinese interior (NCBRAS 1860; 1865); Korean encounter took place within an environment of Japanese cultural imperialism (Kim 2013). Though a number of American RAS members attempted to promote the idea of Korea as a distinguished civilization (NCBRAS 1883; RSKB 1902), they were swimming against the tide of the shifting definitions of sovereignty inherent in East Asia's immersion in the international system (Park 2013). Western relations with Japan were obsessed with its 'modernization' and industrialization; by the turn of the century its status as a civilized nation, and a full member of the international order, in the eyes of Western imperial powers had been achieved (Pyle 2016) - 
though on occasion supremacist attitudes did emerge, in complaints about Japanese 'arrogance' on this score (NCBRAS 1865; ASJ 1891).

The differences in the occupational composition of the branches became increasingly marked as time went on. Shanghai, the most important commercial city in China (NCBRAS 1874), saw its RAS branch increasingly dominated by business interests in the twentieth century. An examination of the membership lists for the year 1919 shows sixty-three members working in business (over one-tenth of the total), representing such prominent firms as Jardine Matheson, Butterfield \& Swire, British American Tobacco, Standard Oil, Nestle, and the Hong Kong and Shanghai Banking Corporation, as well as a collection of railway and telegraph concessions and all of the major English-language Chinese newspapers. It was by far the most cosmopolitan branch, with a wide international reach: twenty-eight of its members resided in the United States, nine in France, six in the Netherlands, four in Japan, and a handful of members in Italy, Germany Russia, Canada, Belgium, and Denmark. The branch also exchanged periodicals with learned societies in India, Singapore, Australia, Canada, the United States, and a host of European countries (NCBRAS 1919).

By contrast, the Korean and Japanese branches were much more intimate affairs. The Korean branch, dominated by missionaries, in its early years also attracted significant interest from the diplomatic community in Seoul (RASKB 1901). It was by far the branch of the society that was most open to women, without whom the society would not have grown at all during the 1920s (RASKB $1920 ; 1925$; 1930). Married missionaries often joined as a couple, and RAS meetings also played a role as an acceptable pastime for a large number of unmarried female missionaries, whose lives were otherwise strictly regimented (Underwood 2003). Another remarkable feature of the Korean branch is the fairly large representation of female medical doctors in its membership. The large female membership illustrates the availability of an unusually wide range of opportunities for adventurous female professionals in Korea. Reflecting the primarily American foreign community in Korea, and the comparative lack of extensive British strategic and commercial interests there, the Korean branch was also dominated by Americans. This was reflected in the leadership: meetings of the executive took place as frequently in the American legation in Seoul, as in the British (RASKB 1911).

Despite being an important asset to the Western population of Korea, the RAS clearly struggled as a result of the international situation. The increasing influence of Japan on Korea's administration diminished the latitude for action of Western diplomats, customs officials, and professionals, and consequently the RAS branch's activities suffered. When the branch began its activities again under the Japanese occupation, its membership stagnated, relying on a small, dedicated core group to continue functioning. The Korean branch did attract a 
degree of interest from new Japanese members in this period, but either in the colonial period or before, there were never more than a few Korean members of the society. Notably, and again mirroring the diminution of Western interests in Korea under Japanese occupation, the Korean branch never attracted many military officers as members.

The Japanese branch, on the other hand, was saturated with the diplomatic staff of all the imperial powers. In contrast to the Korean branch, what is immediately striking about the Japanese is its sheer size. By the 1920s, it had almost achieved the numbers of the North China Branch, an organization covering a much larger area and incorporating a vastly larger Western community. The Japanese branch illustrates, to an extreme extent, something which was a common aspect of all three branches: that despite a large subscribing membership (in the case of Japan, also a membership with a high turnover year on year), the RAS branches continued, by and large, to be run, and receive the majority of their contributions from, a small coterie of elite academics, missionaries, and diplomats, as in the early days of the branch's foundation.

The differences in the constitution and activities of the three branches under discussion should not overshadow the fact that there was a great deal of overlap between them. The small group of prominent and well-known individuals directing the activities of the RAS who were often members of more than one branch: scholarly diplomats such as Thomas Wade, Herbert Giles, Ernest Satow, Horace Allen, J.N. Gubbins, Paul Georg von Möllendorff, and John Jordan were leading members of multiple branches, as were senior businessmen and customs officials such as Robert Hart, John Jamieson (inspector-general and deputy of the Chinese Maritime Customs, respectively), John McLeavy Brown (director of Korean customs), and Thomas Jackson (chairman of HSBC). It is intriguing to note that even high-level political rivals, such as McLeavy Brown and von Möllendorff (Nish 1992), found common cause in their support of the RAS, and presumably comported themselves civilly during meetings of the society - if the two ever had a disagreement, it is not recorded in the minutes.

The process of establishing each branch was largely similar, and the enthusiastic response from Western residents in the early years of each branch's foundation, with rapidly-climbing subscription numbers, suggests that there was an acute understanding of the importance of the RAS's work on Asian studies. There were other curious similarities between each branch, as well. Medical personnel constituted a similar proportion of the membership of all three branches. There was also a common social hierarchy to all three, with the executive committees constituted of a multinational collection of scholarly diplomats; the majority of papers presented by military officers, customs officials, academics, missionaries, or others who collected information in the course of their official duties; and a large and geographically diffuse roster of 
corresponding members, who were not actively involved in the society's research but followed its developments and took advantage of its opportunities for socializing and access.

The ongoing support granted to various branches of the RAS by the British state, through its diplomatic apparatus, and by the Chinese Maritime Customs through the patronage of Robert Hart, suggests its activities were regarded as important to the furtherance of British interests in Northeast Asia. The enthusiastic participation of key business leaders, military officers, and the representatives of other imperial powers would seem to confirm this notion. However, the question remains: was the function of the RAS simply as a locus for elite socialization, the maintenance of informal relationships between Western elites, and the working of soft diplomacy? Or was it a battleground in the ongoing contestation for influence between imperial powers in Northeast Asia, with agents of each power attempting to position themselves within its elite networks to maximum advantage? Examining membership lists alone, it is impossible to draw a strong conclusion. The strategic value of the information presented was variable, though the talks given by customs officers and diplomats may give a wider insight into their official activities. The society was, however, clearly a useful tool connecting influential segments of the Western community, and providing opportunities for the performance of social distinction and establishing claims to expertise in the local context.

\section{CONCLUSION}

The Royal Asiatic Society branches in Shanghai, Seoul, and Tokyo were illustrative of three distinct approaches to East Asian relations in the late nineteenth and early twentieth century. From the semi-colonial space of the Shanghai international settlement, to the streets of Seoul in the early days of the Japanese occupation, to the bustling Pacific trading node of Yokohama, the location and memberships of these three branches of the RAS illustrate the variance of early Western relations in Northeast Asia at the individual level. The evolution of each branch tells a wider story of strategic contestation, commercial expansion, and imperial policy, and the ways in which high-level political maneuvering affects the affairs of local communities and individuals.

This paper has sought to address three questions on the importance of the RAS branches for early international relations between Northeast Asia and the West: whether the antiquarian studies conducted by RAS members had a strategic value for Western powers; whether the differing characteristics of RAS branches were reflective of the shifting international relations between Western states and China, Korea, and Japan; and whether the RAS acted as a location for projecting 
informal influence within these three states. While the examination of just one society's membership, with scant supplementary information available, can only ever partially address such questions, a number of interesting insights do emerge. To the first question, the fact that senior diplomats were heavily involved in RAS activities in the late nineteenth century, as patrons more than as scholarly participants, and the use of the RAS as a platform to disseminate the results of naval surveys, reports of trade routes, and market conditions, seems to support the notion that there was a strategic dimension to the spread of the RAS in Northeast Asia. However, this was a function of the early stages of Western imperial contestation: the North China branch reflects this to a greater extent than the Korea branch, for instance.

As to the second question, much about the developing international situation in this period can indeed be read into the fortunes of the RAS branches. The Shanghai branch illustrates the effect of the growth and increasing permanence of the international settlement, as well as the depressing effects of the Boxer Rebellion on Western communities, during which the society stopped growing. Its membership roster is also a who's who of the business and consular elite of Shanghai, and suggests a highly networked community of interest linking commerce, government, and academia. The Korea branch tells a different story, of an isolated collection of missionary communities, using the society as a social glue. Its membership list, with its increasing representation of Japanese names in the 1910s-1930s, illustrates the advance of the Japanese colonization of Korea. Its increasing proportion of women professionals presages a social change of a more progressive sort. The Japanese branch illustrates the reach of Pacific networks in this period, with its hundreds of members from all across the world, and in its high turnover of members, gives the impression of a highly mobile Western community circulating between semi-imperial sites around Northeast Asia (Van Dijk 2015).

To the third question, the extent to which RAS branches could be utilized to project influence in Northeast Asian states was limited by the society's imperial origins: the audience for the RAS's activities was elite Westerners, in East Asia, North America, and Europe, rather than local officials. The early stated goal of the RAS, 'better acquaintance with each other's motives, plans, and condition, especially amongst the influential classes of the [Chinese] empire' (NCBRAS 1859), was confounded by this lack of interaction, and little knowledge exchange took place with local elites. That said, the society's utility for the networking of diplomatic officials from all of the imperial powers, the use of Western legation compounds as meeting places, and the enthusiastic leadership positions adopted particularly by British and American consuls in these organizations, certainly suggests that they considered the RAS a worthwhile endeavor for transmitting a message of social distinction, local savoir-faire, and a 
regard for the Asian context, at least to other Western elites.

The Second World War, Chinese Revolution, and Korean War fundamentally changed East Asia's relations with the West, but nonetheless the importance of the prior period between 1860 and 1940 should not be discounted. This was the originating period of East Asia's inculcation into the international state system (Lai 2014; Maass 2009); it saw the early seeds of East Asian capitalism sown (Eckert 1991); and it saw the establishment of new concepts of sovereignty, imperial relations, and international norms which resonate to the present day (Park 2013). The Royal Asiatic Society was a microcosm of international relations in flux, as well as a point of convergence, wherein 'the statesman, the philosopher, and the missionary' allied themselves in the realization of the strategic goal of 'adding to the limited stock of information we possess' (NCBRAS 1860). Finally, it serves as a reminder of the importance of networks, associationalism, and social distinction in the operation of international relations, even during the period of high imperial politics.

\section{REFERENCES}

Allen, Horace. 1908. Things Korean: A Collection of Sketches and Anecdotes, Missionary and Imperial. New York: Cornell University Library.

Bell, Morag, Robin Butlin, and Michael Heffernan. 1991. "Geography and Empire." The Geographical Journal 157(3): 347-49.

Beresford, Charles. 1899. The Break-up of China, with an account of its Present Commerce, Currency, Waterways, Armies, Railways, Politics, and Future Prospects. London: Harper \& Brothers.

Bickers, Robert and Johnathan Howlett. 2017. Britain and China, 1840-1970: Empire, finance, and war. New York: Routledge.

Bickers, Robert. 2019. Britain in China. Manchester: Manchester University Press.

Bickers, Robert. 2010. Settlers and Expatriates. Oxford: Oxford University Press. Blaut, James Morris. 1993. The Colonizer's Model of the World. New York: Guilford Press.

Brailey, Nigel. 1992. "Sir Ernest Satow, Japan, and Asia: The Trials of a Diplomat in the Age of High Imperialism." The Historical Journal 35(1): 115-150.

Brother Anthony of Taize and Robert Neff. 2016. Brief Encounters: Early Reports of Korea by Westerners (Irvine, CA: Seoul Selection).

Brunero, Donna (2006), Britain's Imperial Cornerstone in China: The Chinese Maritime Customs Service, 1854-1949. New York: Routledge.

Bueltmann, Tanja. 2017. "Ethnic Associationalism and Networking among the 
Scots in Asia: A Longitudinal Comparison, c.1870 to the Present." In The

Scottish Experience in Asia edited by Tom Devine and Angela McCarthy, 259-82. Cham: Palgrave Macmillan.

Campbell, Charles. 1892. "A Journey through North Korea to the Ch'ang-pai Shan." Proceedings of the Royal Geographical Society 14(3): 141-161.

Cho, Joanne Miyang and Lee M. Roberts. 2018. Transnational Encounters Between Germany and Korea: Affinity in culture and politics since the 1880s. New York: Palgrave Macmillan.

Clifford, Nicholas. 2001. "A Truthful Impression of the Country": British and American Travel Writing in China, 1880-1949. Ann Arbor: University of Michigan Press.

Crosbie, Barry. 2009. "Ireland, Colonial Science, and the Geographical Construction of British Rule in India, c.1820-1870." The Historical Journal 52(4): 963-87.

Devine, Tom and Angela McCarthy. 2017. The Scottish Experience in Asia, c.1700 to the Present: Settlers and Sojourners. Cham: Palgrave Macmillan.

Eckert, Carter J. 1991. Offspring of Empire: The Koch'ang Kims and the Colonial Origins of Korean Capitalism 1876-1945. Seattle: University of Washington Press.

Gannon, Sean. 2019. The Irish Imperial Service: Policing Palestine and Administering the Empire, 1922-1966. Cham: Palgrave Macmillan.

Hoare, James E. 1997. Britain and Korea 1797-1997. Seoul, South Korea: British Embassy.

Kim, Key-hiuk. 1980. The Last Phase of the East Asian World Order: Korea, Japan, and the Chinese Empire, 1860-1882. Berkeley: University of California Press.

Kim, Jeong-ran. 2013. "The borderline of "empire": Japanese Maritime Quarantine in Busan c.1876-1910." Medical History 57(2): 226-248.

Jackson, Isabella and Robert Bickers. 2016. Treaty Ports in Modern China: Law, Land, and Power. London: Routledge.

Lai, Junnan. 2014. "Sovereignty and "Civilization": International Law and East Asia in the Nineteenth Century." Modern China 14(3): 282-314.

Lenson, George Alexander. 1982. Balance of Intrigue: International Rivalry in Korea \& Manchuria, 1884-1899. Tallahassee: University of Florida Press.

Maass, Matthias. 2009. "The International State System Since 1648 and Small States' 'Systemic Resilience'." Asian International Studies Review 10(2): 31-52.

Nish, Ian. 1992. "John McLeavy Brown in Korea." Journal of the British Association of Korean Studies 2: 29-50.

O' Conor, Nicholas. 1893. Diary of Nicholas O'Conor. O'Conor Papers. Churchill Archives Centre, University of Cambridge. 
O'Leary, Richard. 2006. "Robert Hart in China: The Significance of his Irish Roots." Modern Asian Studies 40(3): 583-604.

Osborne, Michael. 2005. "Science and the French Empire." Isis 96(1): 80-87.

Osterhammel, Jurgen. 1999. 'Britain and China 1842-1914', In The Oxford History of the British Empire vol. III edited by Bernard Porter. Oxford: Oxford University Press.

Park, Seo-hyun. 2013. "Changing Definitions of Sovereignty in NineteenthCentury East Asia: Japan and Korea Between China and the West." Journal of East Asian Studies 13(2): 281-307.

Pyle, Kenneth B. 2006. "Profound Forces in the Making of Modern Japan." Journal of Japanese Studies 32(2): 393-418.

Reed, Charles V. 2016. Royal tourists, colonial subjects and the making of a British world, 1860-1911. Manchester: Manchester University Press.

Royal Asiatic Society. 1865-1918. Journal of the North China Branch of the Royal Asiatic Society. Shanghai.

Royal Asiatic Society. 1873-1924. Transactions of the Asiatic Society of Japan. Yokohama.

Royal Asiatic Society. 1900-1934. Transactions of the Royal Asiatic Society Korea Branch. Seoul.

Schmid, Andre. 2002. Korea Between Empires 1895-1919. New York: Columbia University Press.

School of Oriental and African Studies (SOAS). 1926. China: Maritime Customs V

- Customs Papers No. 44. Customs Service: Officers in Charge, 1859-1921. Shanghai: Inspectorate General of Customs. Special Collections, School of Oriental and African Studies, University of London.

Uchida, Jun. 2011. Brokers of Empire: Japanese Settler Colonialism in Korea, 1876-1945. Cambridge: Harvard University Press.

Underwood, Elizabeth. 2003. Challenged Identities: North American Missionaries in Korea, 1884-1934. Seoul: Royal Asiatic Society.

Underwood, Horace H. 1948. "Korea Branch of the Royal Asiatic Society, its

Past and Present." Transactions of the Korea Branch of the Royal Asiatic Society 31: 1-8.

Van de Ven, Hans. 2006. "Robert Hart and the Chinese Maritime Customs Service." Modern Asian Studies 40(3): 545-48.

Van Dijk, Kees. 2015. Pacific Strife: The Great Powers and their Political and Economic Rivalries in Asia and the Western Pacific 1870-1914. Amsterdam: Amsterdam University Press.

Walton, Joseph. 1900. China and the Present Crisis, with notes on a visit to Japan and Korea. London: Sampson, Low, Marston \& Co.

Woo, Young-sik. 1987. Earlier Canadian Missionaries in Korea: A Study in History 1888-1895. Society for Korean and Related Studies, Mississauga. 


\section{ENDNOTES}

1 I am obliged to the library of the Royal Asiatic Society Korea Branch, Seoul, for allowing me access to their special collections. When citing material from the Transactions of the various RAS branches, I employ the following abbreviations: Journal of the North China Branch of the Royal Asiatic Society: NCBRAS; Transactions of the Royal Asiatic Society Korea Branch: RASKB; Transactions of the Asiatic Society of Japan: ASJ. 